\title{
Chlorhexidine Gluconate Cleansing
}

National Cancer Institute

\section{Source}

National Cancer Institute. Chlorhexidine Gluconate Cleansing. NCI Thesaurus. Code C111375.

The process of washing the skin using chlorhexidine gluconate. 